\title{
A Meta-analysis of Antimicrobial Peptide Effects on Intestinal Bacteria, Immune Response, and Antioxidant Activity of Broilers
}

\author{
M. M. Sholikin ${ }^{\mathrm{a}, \mathrm{d}}$, A. T. Wahyudi ${ }^{\mathrm{b}}$, A. Jayanegara ${ }^{\mathrm{a}, \mathrm{c}, *}$, J. Nomura ${ }^{\mathrm{e}}$, \& Nahrowi ${ }^{\mathrm{c}}$ \\ ${ }^{a}$ Animal Feed and Nutrition Modelling (AFENUE) Research Group, Department of Nutrition and Feed Technology, \\ Faculty of Animal Science, IPB University \\ bDepartment of Biology, Faculty of Mathematics and Natural Sciences, IPB University \\ 'Department of Nutrition and Feed Technology, Faculty of Animal Science, IPB University \\ ${ }^{\mathrm{d} G r a d u a t e}$ School of Nutrition and Feed Science, Faculty of Animal Science, IPB University \\ Jalan Agatis, Kampus IPB Dramaga, Bogor 16680, Indonesia \\ eTraining Division for School Health Nursing (Yogo) Teachers, Faculty of Education Chiba University, Japan \\ *Corresponding author: anuraga.jayanegara@gmail.com \\ (Received 26-08-2020; Revised 13-11-2020; Accepted 30-11-2020)
}

\begin{abstract}
This study used a meta-analysis to systematically assess the effect of antimicrobial peptide (AMP) addition on the number of bacteria, immune responses, and antioxidant activity of broilers. The database was compiled from 29 post evaluation articles that were found in search engines consisted of 36 experiments and 111 data. The mixed model method was used to assess the effect of AMP, with AMP addition level as a fixed effect and experiment as a random effect. The fixed effect was tested for linear and quadratic models. The quadratic model was retained when significant at $p<0.05$ but turned into its corresponding linear model when insignificant. In the starter phase, AMP addition decreased the number of bacteria in the ileum (coliform and total aerobic bacteria (TAB); $(\mathrm{p}<0.05)$, the caecum (Clostridium spp., Escherichia coli, coliform, and lactic acid bacteria (LAB); p<0.05), and excreta (Clostridium spp.; $\mathrm{p}<0.1)$. Similarly, the number of bacteria also declined in the ileum $($ Escherichia coli, $\mathrm{p}<0.05 ; \mathrm{TAB}, \mathrm{p}<0.1)$, the caecum $(\mathrm{LAB} ; \mathrm{p}<0.1)$, and excreta (Clostridium spp.; $\mathrm{p}<0.05)$ of broilers in the finisher phase. There were significant improvements in immune response and antioxidant activity in starter broiler, as indicated by the titer of Newcastle disease (ND) antibody, bursal index, spleen index, and thymus index $(\mathrm{p}<0.05)$ due to AMP addition. Variables of immunoglobulin M (IgM), cluster of differentiation 4 (CD4), ND antibody titer, bursal index, spleen index, and thymus index were also significantly increased $(\mathrm{p}<0.05)$ while superoxide dismutase activity (SOD activity) tended to increase $(\mathrm{p}<0.1)$ in finisher broiler following the AMP addition. In short, AMP addition is able to suppress the number of pathogenic bacteria and increase the immune response and antioxidant activity of broilers.
\end{abstract}

Keywords: antimicrobial peptide; gut bacteria; immune response; meta-analysis; antioxidant activity

\section{INTRODUCTION}

The awareness of the world community on the need for healthy broiler meat has increased recently. Trends in the use of conventional antibiotic growth promoters (AGPs) in broiler diets have become obsolete due to their negative effects to generate resistant pathogenic bacteria and their residual presence in broiler products (Bahar \& Ren, 2013; Leeson \& Summers, 2009). Accordingly, there is a need to substitute AGP with other compounds, particularly those that originated or are derived from nature like antimicrobial peptides (Gadde et al., 2017; Xiao et al., 2015; Wang et al., 2016). Antimicrobial peptide (AMP) is composed of 4 to 99 amino acids (mostly cationic) that can act as an antifungal, antiviral, antibacterial (i.e., bacteriocidic and bacteriostatic), immunomodulatory, anticancer, antitumor, and antioxidant agent (Bahar \& Ren, 2013; Ikeda,
2001; Li et al., 2012; Park \& Yoe, 2017a; Park \& Yoe, 2017b; Wu et al., 2018; Yi et al., 2014; Zhao et al., 2013). AMP substances can be isolated from animal tissues (e.g., lactoferrin, colostrum, swine antibacterial peptide, and lysozyme), recombinant product (e.g., cecropin $\mathrm{AD}$-asparagine and microcin J25), plants (e.g., thionine and potamic), insects (e.g., defensin-like peptides and diptericin), microbes (e.g., gramicidin and nisin), and amphibians (e.g., magainin) (Bahar \& Ren, 2013; Ikeda, 2001; Kim et al., 2005; Li et al., 2017; Park \& Yoe, 2017b; Wang et al., 2020; Zhao et al., 2013). The use of AMP as an alternative to substitute conventional AGPs has advantages such as high stability against digestive enzyme degradation, i.e., cysteine-rich peptide (Silva et al., 2000). Also, it tends not to cause resistance effects (due to the $\beta$-sheet structure) and has a broad spectrum against various types of pathogens (Bradshaw, 2003; Yi et al., 2014). 
Based on in vitro studies, the AMP substance, such a defensin, can inhibit gram-positive bacteria (e.g., Bacillus subtilis and Staphylococcus aureus), Escherichia coli, and other types of fungi (Li et al., 2012; Wang et al., 2016). In addition, in vitro studies also reported the reduction of oxidative stress as the effect of AMP addition (Ikeda, 2001, Wang et al., 2019). Furthermore, in vivo study reported the success of AMP to increase productivity through the improvement of the immune response and small intestine ecosystem in the broiler (Choi et al., 2013a; Choi et al., 2013b; Wang et al., 2020). The addition of AMP also shows a positive response to antibody titer (Bai et al., 2019). Also, Gong et al. (2016) report that lysozyme administration in broilers had no effect on aerobic bacteria, coliforms, and Clostridium perfringens. Therefore, this study was conducted to assess the effects of AMP addition on the number of bacteria, immune responses, and antioxidant activity of broiler by integrating data from previously published reports.

\section{MATERIALS AND METHODS}

\section{Database Development}

A database was developed based on kinds of literature that reported effects of AMP addition on the number of bacteria, immune responses, and antioxidant activity of broiler. The kinds of literature were found in Science Direct and Google Scholar, by using various keywords such as "antimicrobial peptide", "bacterial number", "immune response", "antioxidant activities" and or "broiler". A total of 43 journal articles with digital object identifiers were found. After title and abstract suitability evaluation, 29 articles were entered into the database. The evaluation criteria used were: (1) the article was published in English, (2) the AMP level was determined, and (3) the in vivo experiment used a fast-growing broiler. If an article consisted of two or more experiments, the experiments were individually encoded. In total, there were 36 experiments used for meta-analysis that comprised of 111 data points, as depicted in Table 1. This meta-analysis study followed the preferred reporting items for systematic review and meta-analysis protocols (PRISMA-P) (Shamseer et al., 2015).

The addition levels of AMP were varied, in a range of 0 (control) to $600 \mathrm{mg} \mathrm{kg}^{-1}$ of diet. The used AMP was derived from animal tissue purification (e.g., swine antibacterial peptides, lactoferrin, and bee venom), recombinant products (i.e., microcin J25, AMP-A3, and AMP-P5), and plant-based protein extraction (i.e., bioactive peptides from canola, sesame, and soybean). Broilers were maintained in two phases: starter (ranged between 1-21 days) and finisher (ranged between 22-42 days). Broiler strains used in the meta-analysis were varied, namely Arbor Acres, Cobb 500, Lingnan, Lohmann, Hubbard, and ROSS 308.

The assessed variables were the number of bacteria (e.g. Clostridium spp., Escherichia coli, coliform, lactic acid bacteria (LAB), and total aerobic bacteria (TAB)), immune responses (e.g., immunoglobulin A (IgA), immunoglobulin $M(\operatorname{IgM})$, cluster of differentiation 3 (CD3), cluster of differentiation 4 (CD4), antibody titer, bursal index, spleen index, and thymus index), and antioxidant activity (e.g., total superoxide dismutase (TSOD), total antioxidant activity (TAA), and superoxide dismutase activity (SOD activity)). Data on growth performance, carcass characteristics, and small intestinal morphology were excluded since they were presented in a separate paper and submitted elsewhere (Sholikin et al., 2020).

\section{Data Analysis}

Data analysis was performed in R software version 3.6.3 with additional packages such as "nlme" and "tidyverse" (Bates et al., 2015; Pinheiro et al., 2020; R Core Team, 2020). Linear mixed models (LMM) methodology was performed for the present meta-analysis. The addition level of AMP was fixed effects, while the experiment was random effects (Gałecki \& Burzykowski, 2013; Sauvant et al., 2008; St-Pierre, 2001). The mathematical model follows the following equation.

$\mathrm{Y}_{\mathrm{ij}}=\beta_{0}+\beta_{1}$ Level $_{\mathrm{ij}}+$ Experiment $_{\mathrm{i}}+$ Experiment $_{\mathrm{i}}$ Level $_{\mathrm{ij}}+\mathrm{e}_{\mathrm{ij}}(1)$

$\mathrm{Y}_{\mathrm{ij}}=\beta_{0}+\beta_{1}$ Level $_{\mathrm{ij}}+\beta_{2}$ Level $_{\mathrm{ij}}^{2}+$ Experiment $_{\mathrm{i}}+$ Experiment $_{\mathrm{i}}$ Level $_{\mathrm{ij}}+\mathrm{e}_{\mathrm{ij}}$ (2)

where (1) linear mixed model of the $1^{\text {st }}$ order 1 , (2) linear mixed model of the $2^{\text {nd }}$ order, $Y_{i j}$ was dependent variable, $\beta_{0}$ was overall intercept across all studies (fixed effect), $\beta_{1}$ was linear regression coefficient of $Y$ on Level (fixed effect), $\beta_{2}$ was quadratic regression coefficient of $Y$ on Level (fixed effect), Level ${ }_{i j}$ was value of the continuous predictor variable (AMP addi-

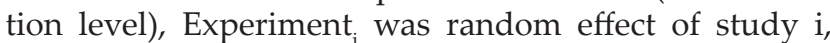

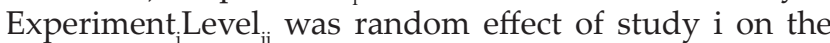
regression coefficient of $Y$ on Level in study $i, e_{i j}$ was the unexplained residual error. The $\mathrm{p}$-value, root mean square error (RMSE), and Akaike information criterion (AIC) were used to evaluate the suitability of statistical models (Gałecki \& Burzykowski, 2013; Chai et al., 2014). If the p-value was less than or equal to 0.05 , the result was significant. In addition, there was a tendency to be significant if only the p-value ranged between 0.05 and 0.1 .

\section{RESULTS}

The effects of the AMP addition level on the number of bacteria are shown in Table 2. In the ileum, the number of bacteria (coliform and TAB) linearly declined $(\mathrm{p}<0.05)$ with the increasing AMP level in the starter broiler. Similarly, Escherichia coli population linearly decreased $(\mathrm{p}<0.05)$ due to the AMP addition for the finisher broiler, while the TAB tended to decrease linearly $(p<0.1)$. In the caecum of the starter broiler, there was a linear decrease of bacterial numbers, such as Clostridium spp., coliform, Escherichia coli, and LAB ( $\mathrm{p}<0.05)$ following the AMP addition. Meanwhile, the TAB tended to have a linear increase in finisher broiler $(p<0.1)$. In the excreta of the starter broiler, the number of Clostridium spp. tended to decline linearly $(p<0.1)$. The other bacteria species in the small intestine were not affected by the AMP addition. 


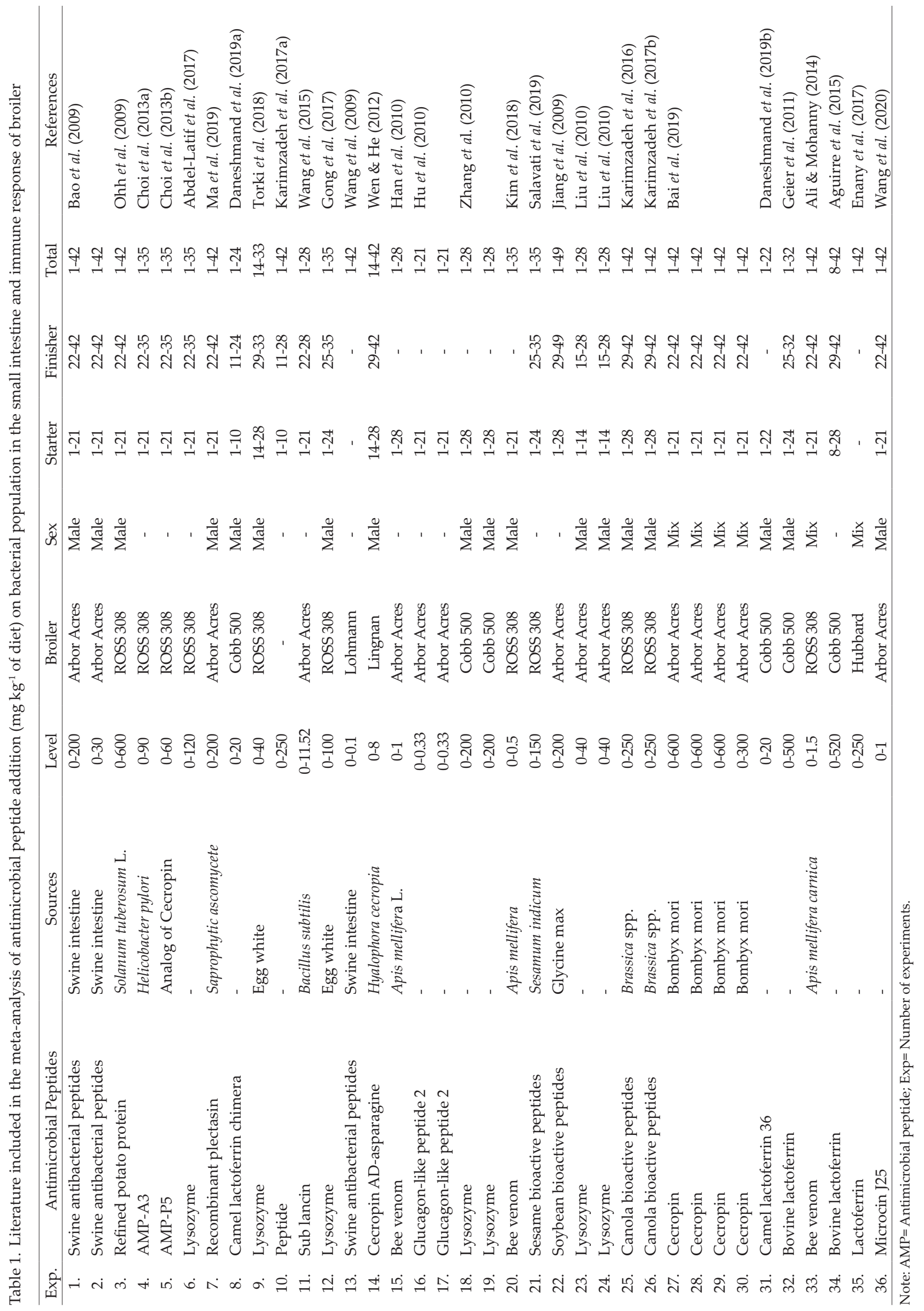




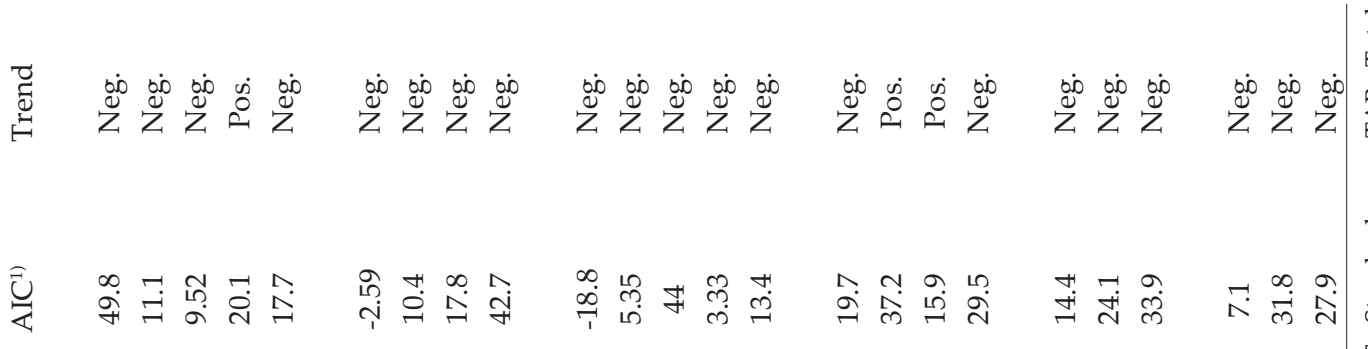

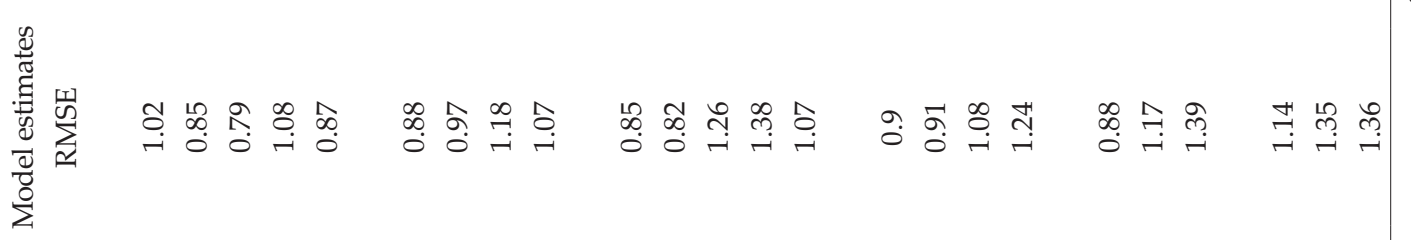

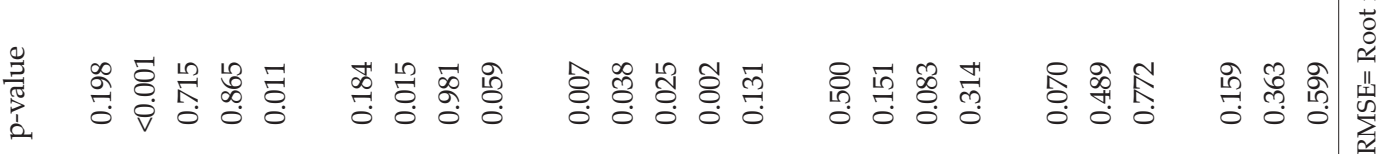

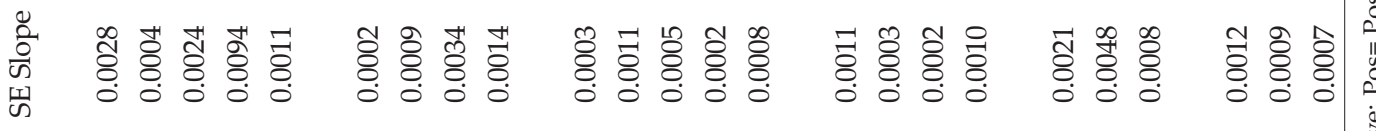

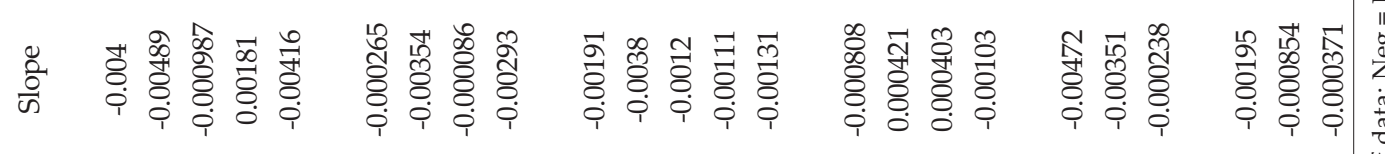

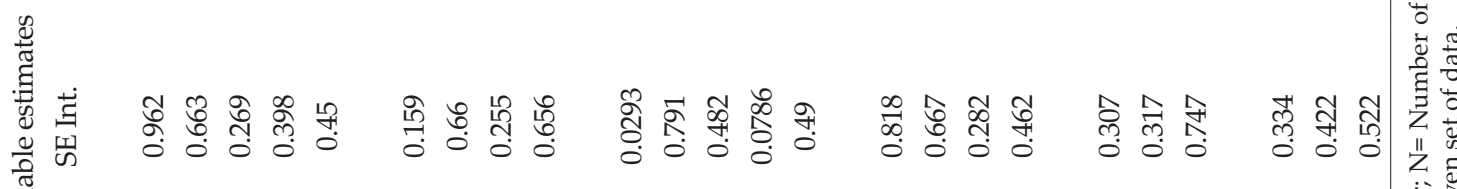

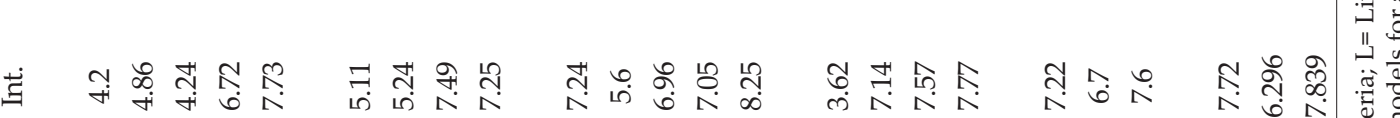

Z 응 이

ฮั

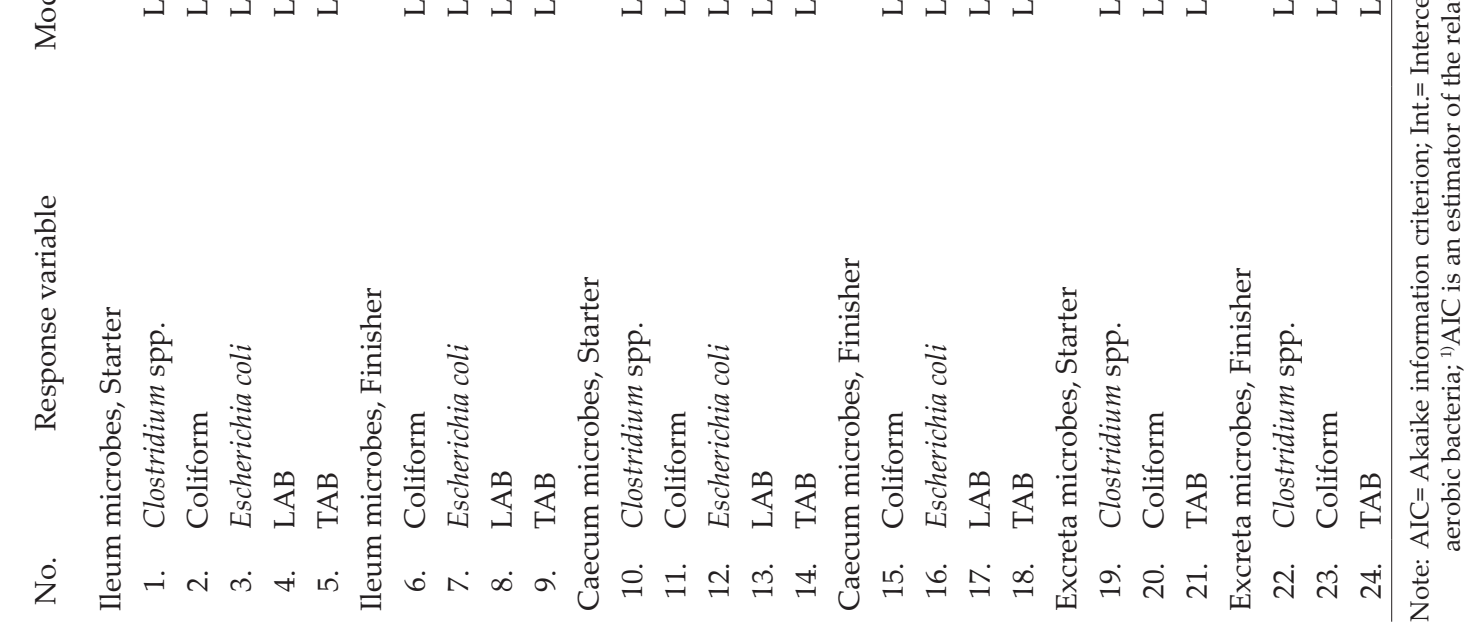


The AMP addition possessed a linear pattern on immune response $(\mathrm{p}<0.05)$ and antioxidant activity $(p<0.1)$ of the broiler (Table 3$)$. In the starter phase, AMP addition linearly increased $(p<0.05)$ ND antibody titers and lymphoid organs (i.e., bursal index, spleen index, and thymus index). Similarly, immunoglobulin and complement (IgM; CD4), ND antibody titer, and the spleen organs of the finisher broiler increased in a linear pattern due to AMP addition $(p<0.05$; Table 3$)$, whereas IgA and CD3 were not affected. The effect of AMP addition tended $(p<0.1)$ to linearly elevate SOD activity, while TAA was not influenced in finisher broiler. The addition of AMP did not affect TSOD in the starter broiler.

A previous study by Sholikin et al. (2020) showed that optimal AMP levels based on feed conversion ratio variables were 337, 359, and $371 \mathrm{mg} \mathrm{kg}^{-1}$ in the starter, finisher, and total phases, respectively. The reduction of total Clostridium spp. was following equation (3). This was reduced by $8.85 \%$ or from 7.24 to $6.60 \log 10 \mathrm{cfu} \mathrm{g}^{-1}$. The normal rate of Clostridium spp. ranged from 7.15 up to $7.27 \log 10 \mathrm{cfu} \mathrm{g}^{-1}$ at the ileum of broiler starter (Choi et al., 2013b; Chowdhury et al., 2018). Based on equation (4), IgM increased to about $49.33 \%$ from 0.58 to $0.87 \mathrm{~g}$ $\mathrm{L}^{-1}$. The IgM under normal conditions by Ma et al. (2019) is $0.50 \mathrm{~g} \mathrm{~L}^{-1}$. Based on equation (5), SOD activity increased from 9.35 up to $21.92 \%$ inhibition. Karimzadeh et al. (2017b) reported that normal broiler SOD activity was $11.40 \%$ inhibition.

$$
\begin{aligned}
& \mathrm{Y}_{\text {Clostridiumspp. }}=7.24-0.00191 \mathrm{X}_{\text {level }} ;(\mathrm{p}=0.007) \\
& \mathrm{Y}_{\text {IgM }}=0.58+0.000797 \mathrm{X}_{\text {level }} ;(\mathrm{p}=0.037) \\
& \mathrm{Y}_{\text {SODactivity }}=9.35+0.0351 \mathrm{X}_{\text {level }} ;(\mathrm{p}=0.01)
\end{aligned}
$$

where (3) Clostridium spp. regression equation based on Table 2 row 10, (4) IgM regression equation based on Table 3 row 2, (5) SOD activity regression equation based on Table 3 row 17, Y was dependent variable (variable), and $\mathrm{X}$ was independent variable (level of AMP).

\section{DISCUSSION}

\section{Effect of AMP Addition on Bacteria Population in The Small Intestine of Broiler}

In general, AMP addition is able to reduce the number of pathogenic bacteria in the small intestine of broiler both in starter and finisher phases. Pathogenic bacteria in the small intestine may cause a variety of negative effects, especially tissue damage and also the production of toxic compounds. The accumulation of toxic compounds leads to the emergence of various types of metabolic diseases and may reduce growth performance, nutrient digestibility, and immune response. With regard to the effect of AMP on pathogenic bacteria, the present finding highlights the reduction of the number of Clostridium spp. Clostridium spp. is a gram-positive bacterium that causes botulism (Chalk et al., 2019; Johnson, 2019). The percentage of Clostridium spp. found in the ileum and the caecum of broiler were
$9.69 \%$ and $39.26 \%$ of total bacteria, respectively ( $\mathrm{Lu}$ et al., 2003). Choi et al. (2013a) reported the decline of Clostridium spp. in the excreta due to AMP-A3 addition (starter and finisher phase). The decline of Clostridium spp. is possibly due to the ability of AMP in the form of cecropin-A-maganin-2 (CAMA) to inhibit or even kill gram-positive bacteria (Vizioli et al., 2000). CAMA is composed of an amphipathic terminal base in CA and N-terminal (hydrophobic region) base in MA that both terminals were effective in damaging bacterial cell membranes (Park \& Yoe, 2017a; Xiao et al., 2015; Yue et al., 2020; Zhang et al., 2017).

Escherichia coli and TAB are categorized as coliform group bacteria (Malcolm, 1938). Coliform possesses several characteristics, such as gram negative, lactose base energy source, and aerobic or anaerobic facultative (Malcolm, 1938). Bacteria in this group were able to produce various types of toxic such as indole, skatole, and thionine that may trigger cancer and cause diarrhea (Anabrees et al., 2013; Girard \& Bee, 2020). The present study confirms the reduction of coliform bacteria numbers like Escherichia coli in the ileum and caecum due to AMP addition. This finding was in accordance with previous studies that showed the reduction of coliform bacteria in the ileum after the addition of AMP-P3, lysozyme, and sesame meal bioactive peptide (Choi et al., 2013b; Gong et al., 2017; Salavati et al., 2019). Some types of AMP, such as cecropin (isolated from Hermetia illucens) and lysozyme were also effective in inhibiting gram negative bacteria like Escherichia coli (Pellegrini et al., 1992; Park \& Yoe, 2017a). Lysozyme was able to hydrolyze cell walls of both gram-positive and gramnegative bacteria that are composed of peptidoglycan (Ragland \& Criss, 2017). The number of TAB decreased in the small intestine and also feces due to the addition of AMP in the form of AMP-A3, AMP-P5, cecropin, and recombinant plectacin (Choi et al., 2013b; 2013a; Ma et al., 2019; Wen \& He, 2012).

In contrast to the present finding, Salavati et al. (2019) reported increased LAB number due to lysozyme. Those different findings might be related to the diversity of interactions of AMP against various types of LAB. For instance, lysozyme was reported to have inhibitory activity against several types of LAB like Lactobacillus brevis (Tribst et al., 2008). Lüders et al. (2003) reported that LAB such as Lactobacillus curvatus LTH1174 and Pediococcus acidilactici LMG 2351 were capable of producing AMPs Curvacin A and Pediocin PA-1.

The reduction of Clostridium perfringens population for about $10.9 \%$ increased the population of LAB in the ileum for about 2.3\% (Askelson et al., 2018). Based on $16 \mathrm{~S}$ rDNA sequences, the number of Lactobacillus spp. in the ileum of the broiler was around $67 \%$ of total bacteria (Lu et al., 2003). Lactobacillus spp. could adhere to the small intestine walls and also capable of producing organic acids such as short chain fatty acids (e.g., butyric, propionic, and acetic) and also lactic acid (Rowland et al., 2018). These organic acids reduce $\mathrm{pH}$ in the small intestine and provide energy available for epithelial cells (Krajmalnik-Brown et al., 2012; Shang et al., 2018). Energy availability increases cell metabolism so that small intestinal morphology could be maintained. 


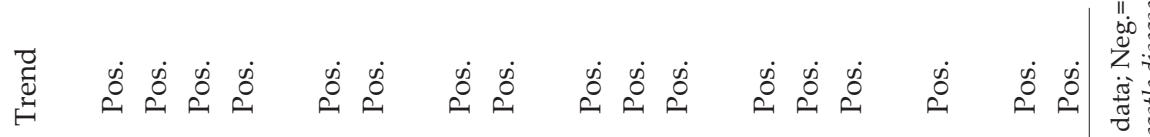

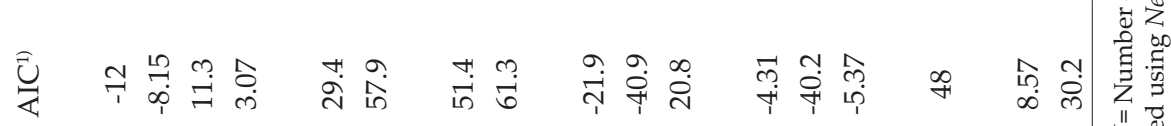

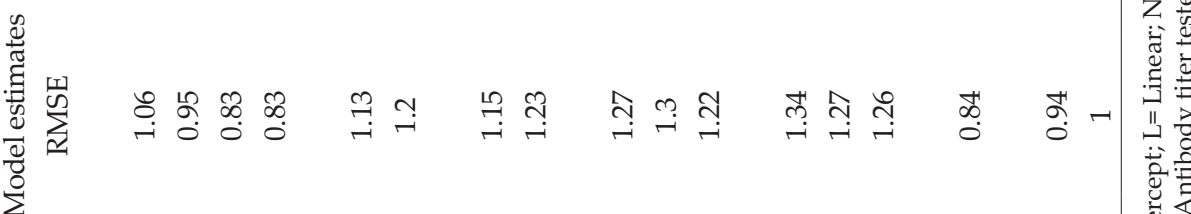

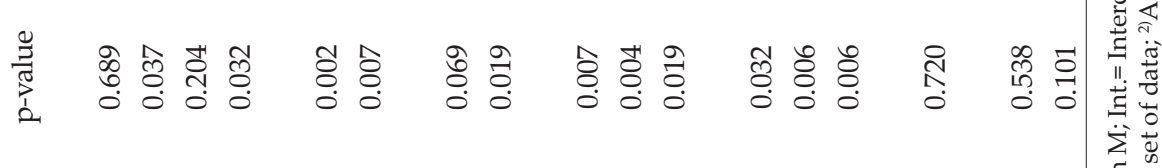

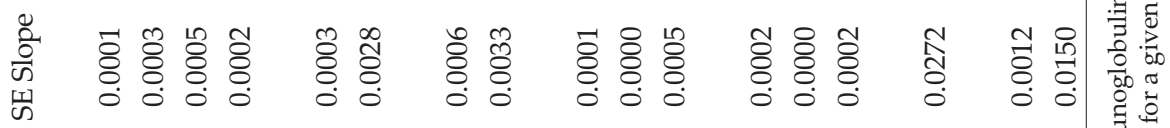
思

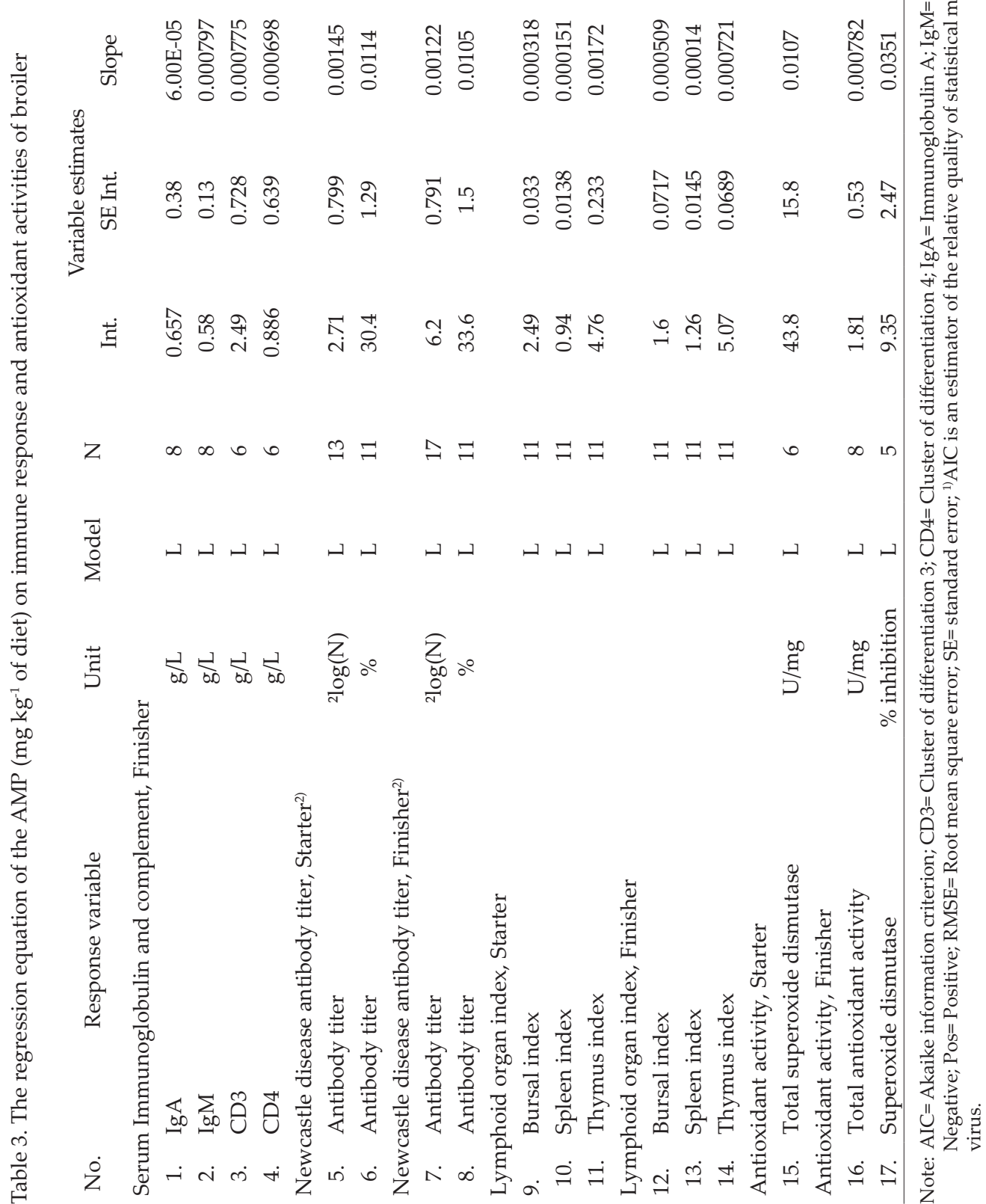


In addition, $\mathrm{LAB}$ and Bacillus subtilis were reported to increase gene expression from mucin that was useful for maintaining mucosa thickness (Aliakbarpour et al., 2012).

\section{Effect of AMP Addition on Immune Response and Antioxidant Activity of Broiler}

Generally, AMP addition positively affects the broiler immune response such as immunoglobulin, complement, ND antibody titer, and lymphoid organs. Immunoglobulin is the product of B cells (humoral immunity) used to fight antigens (Schat et al., 2013). IgA serves an important role in mucosal immunity (in parts of body's secretory organs, respiratory tract, digestive tract, and skin surface) to prevent the attachment of bacteria and viruses to the mucous membrane (Bonner et al., 2009; Fagarasan \& Honjo, 2003; Macpherson \& Slack, 2007; Schat et al., 2013). Meanwhile, IgM has a role as a binder of bacteria that attached to the mucosa (Jazayeri et al., 2019; Murguia-Favela et al., 2017; Sharma, 2017). Complement is a part of cellular immunity and has an important role in $\mathrm{T}$ lymphocytes. The function of CD3 is to activate cytotoxic T cells and T helper cells, while $\mathrm{CD} 4$ is a receptor of $\mathrm{T}$ helper cells that act as a marker (communicating with antigen-presenting cells) (Schat et al., 2013). Similar to the finding of Bai et al. (2019), the lymphoid organ index was reported to increase in this study. The thymus is the site of differentiation of $\mathrm{T}$ lymphocytes, while the bursa of fabricius is a site of maturation of B lymphocytes (Schat et al., 2013). In line with the improvement of serum immunoglobulin and complement variables, broilers challenged by the Newcastle disease virus and given AMP could increase their antibody titers in both starter and finisher phases. Similar findings by Bai et al. (2019) who used cecropin and seaweed powder to increase antibody titers. The increase of IgM, CD4 cell, the lymphoid organ index, and antibody titer have a positive effect on the immune status of broilers. AMP increased innate and adaptive immunity by improving proinflammatory and anti-inflammatory modulation, chemotaxis activity, and direct effects on adaptive immunity (Wang et al., 2016). AMP increased the number of $\mathrm{T}$ cells and their proliferation products in blood peripherals and also increased IgG, IgM, and IgA in pigs (Ren et al., 2015; Yuan et al., 2015).

Antioxidant activity of broiler could be assessed based on its SOD activity status. A similar result to the present finding, Karimzadeh et al. (2017b) reported the increase of SOD activity in broilers at 42 days by AMP addition in the form of recombinant plectacin. SOD is an enzyme for neutralizing the activity of free radicals such as peroxide and super peroxide (Corpas et al., 2006). The proline or arginine-rich AMP (PR-39) proved to inhibit the activity of nicotinamide adenine dinucleotide phosphate oxidase (NADPH oxidase) from polymorphonuclear leukocytes by blocking the assembly of these enzymes (Ikeda, 2001). The NADPH oxidase itself is the main source of super peroxide. The ability of AMP to suppress free radicals was reported through two main mechanisms, i.e., increasing SOD activity and catalyzing enzymes, and damaging the integrity of NADPH oxidase that is influenced by the activity of N-terminal groups and carboxylic acid groups (Ikeda, 2001; Xiao et al., 2015).

\section{CONCLUSION}

The present meta-analysis revealed the effect of AMP addition in the form of the decline, not only the number of Clostridium spp. at the caecum and excreta in starter broiler but also the number of Escherichia coli at the ileum in finisher broiler and at the caecum in starter broiler. Moreover, the number of coliforms at the ileum and the caecum in the starter broiler and TAB at the ileum in the starter and finisher broiler were decreased as the effect of the addition of AMP. The immune response and antioxidant activity of the broiler could also be improved as indicated by the positive responses of serum immunoglobulin $\mathrm{M}$ and cluster of differentiation 4, antibody titer, index of lymphoid organs, and SOD activity.

\section{CONFLICT OF INTEREST}

Anuraga Jayanegara and Nahrowi serve as editors of the Tropical Animal Science Journal, but have no role in the decision to publish this article. We also declare that there is no conflict of interest with any financial, personal, or other relationships with other people or organization related to the material discussed in the manuscript.

\section{ACKNOWLEDGEMENT}

The present study was financially supported by Ministry of Education and Culture, the Republic of Indonesia through the scholarship scheme namely "Masters Education Towards Doctor for Excellent Bachelor (PMDSU)" in the 2019 fiscal year with the number of contract 3/E1/KP.PTNBH/2019. This study was also a part of sandwich-like program (PKPI) at Chiba University, Japan in 2019 with grant number T/2134/D3.2/KD.02.00/2019.

\section{REFERENCES}

Abdel-Latif, M. A., A. H. El-Far, A. R. Elbestawy, R. Ghanem, S. A. Mousa, \& H. S. Abd El-Hamid. 2017. Exogenous dietary lysozyme improves the growth performance and gut microbiota in broiler chickens targeting the antioxidant and non-specific immunity mRNA expression. PLoS ONE. 12:1-17. https://doi.org/10.1371/journal.pone.0185153

Aguirre, A. T. A., S. P. Acda, A. A. Angeles, M. C. R. Oliveros, F. E. Merca, \& F. A. Cruz. 2015. Effect of Bovine Lactoferrin on growth performance and intestinal histologic features of broilers. Philipp. J. Vet. Anim. Sci. 41:12-20.

Ali, A. \& K. Mohanny. 2014. Effect of injection with bee venom extract on productive performance and immune response of broiler chicks. Journal of Animal and Poultry Production. 5:237-246. https://doi.org/10.21608/jappmu.2014.69561

Aliakbarpour, H. R., M. Chamani, G. Rahimi, A. A. Sadeghi, \& D. Qujeq. 2012. The Bacillus subtilis and lactic acid bacteria probiotics influences intestinal mucin gene expression, histomorphology and growth performance in broilers. Asian-Australas. J. Anim. Sci. 25:1285-1293. https://doi. org/10.5713/ajas.2012.12110 
Anabrees, J., F. Indrio, B. Paes, \& K. AlFaleh. 2013. Probiotics for infantile colic: A systematic review. BMC Pediatr. 13:186. https://doi.org/10.1186/1471-2431-13-186

Askelson, T. E., C. A. Flores, S. L. Dunn-Horrocks, Y. DersjantLi, K. Gibbs, A. Awati, J. T. Lee, \& T. Duong. 2018. Effects of direct-fed microorganisms and enzyme blend co-administration on intestinal bacteria in broilers fed diets with or without antibiotics. Poult. Sci. 97:54-63. https://doi. org/10.3382/ps/pex270

Bahar, A. \& D. Ren. 2013. Antimicrobial peptides. Pharmaceuticals. 6: 1543-1575. https://doi.org/10.3390/ ph6121543

Bai, J., R. Wang, L. Yan, \& J. Feng. 2019. Co-supplementation of dietary seaweed powder and antibacterial peptides improves broiler growth performance and immune function. Braz. J. Poult. Sci. 21:1-9. https://doi. org/10.1590/1806-9061-2018-0826

Bao, H., R. She, T. Liu, Y. Zhang, K. S. Peng, D. Luo, Z. Yue, Y. Ding, Y. Hu, W. Liu, \& L. Zhai. 2009. Effects of pig antibacterial peptides on growth performance and intestine mucosal immune of broiler chickens. Poult. Sci. 88:291-297. https://doi.org/10.3382/ps.2008-00330

Bates, D., M. Mächler, B. Bolker, \& S. Walker. 2015. Fitting linear mixed-effects models using lme4. J. Stat. Softw. 67:1-48. https://doi.org/10.18637/jss.v067.i01

Bauer, E., S. Jakob, \& R. Mosenthin. 2005. Principles of physiology of lipid digestion. Asian-Australas. J. Anim. Sci. 18:282-295. https://doi.org/10.5713/ajas.2005.282

Bonner, A., A. Almogren, P. B. Furtado, M. A. Kerr, \& S. J. Perkins. 2009. Location of secretory component on the Fc edge of dimeric IgA1 reveals insight into the role of secretory IgA1 in mucosal immunity. Mucosal Immunol. 2:7484. https://doi.org/10.1038/mi.2008.68

Bradshaw, J. P. 2003. Cationic antimicrobial peptides: Issues for potential clinical use. BioDrugs. 17:233-240. https://doi. org/10.2165/00063030-200317040-00002

Caldwell, D. J., H. D. Danforth, B. C. Morris, K. A. Ameiss, \& A. P. McElroy. 2004. Participation of the intestinal epithelium and mast cells in local mucosal immune responses in commercial poultry. Poul. Sci. 83:591-599. https://doi. org/10.1093/ps/83.4.591

Chai, T. \& R. R. Draxler. 2014. Root mean square error (RMSE) or mean absolute error (MAE)? - Arguments against avoiding RMSE in the literature. Geosci. Model Dev. 7:12471250. https://doi.org/10.5194/gmd-7-1247-2014

Chalk, C. H., T. J. Benstead, J. D. Pound, \& M. R. Keezer. 2019. Medical treatment for botulism. Cochrane Database of Sys. Rev. 4:1465-1858. https://doi.org/10.1002/14651858. CD008123.pub4

Choi, S. C., S. L. Ingale, J. S. Kim, Y. K. Park, I. K. Kwon, \& B. J. Chae. 2013a. An antimicrobial peptide-A3: Effects on growth performance, nutrient retention, intestinal and faecal microflora and intestinal morphology of broilers. Br. Poult. Sci. 54:738-746. https://doi.org/10.1080/00071668.20 13.838746

Choi, S. C., S. L. Ingale, J. S. Kim, Y. K. Park, I. K. Kwon, \& B. J. Chae. 2013b. Effects of dietary supplementation with an antimicrobial peptide-P5 on growth performance, nutrient retention, excreta and intestinal microflora and intestinal morphology of broilers. Anim. Feed Sci. Technol. 185:7884. https://doi.org/10.1016/j.anifeedsci.2013.07.005

Chowdhury, S., G. P. Mandal, A. K. Patra, P. Kumar, I. Samanta, S. Pradhan, \& A. K. Samanta. 2018. Different essential oils in diets of broiler chickens: 2. Gut microbes and morphology, immune response, and some blood profile and antioxidant enzymes. Anim. Feed Sci. Technol. 236:3947. https://doi.org/10.1016/j.anifeedsci.2017.12.003

Corpas, F. J., A. Fernández-Ocaña, A. Carreras, R. Valderrama, F. Luque, F. J. Esteban, M. Rodríguez-Serrano, M.
Chaki, J. R. Pedrajas, L. M. Sandalio, L. A. del Río, \& J. B. Barroso. 2006. The expression of different superoxide dismutase forms is cell-type dependent in olive (Olea europaea L.) leaves. Plant Cell Physiol. 47:984-994. https://doi. org/10.1093/pcp/pcj071

Daneshmand, A., H. Kermanshahi, M. H. Sekhavati, A. Javadmanesh, \& M. Ahmadian. 2019a. Antimicrobial peptide, cLF36, affects performance and intestinal morphology, microflora, junctional proteins, and immune cells in broilers challenged with E. coli. Sci. Rep. 9:14176. https:// doi.org/10.1038/s41598-019-50511-7

Daneshmand, A., H. Kermanshahi, M. H. H. Sekhavati, A. Javadmanesh, M. Ahmadian, M. Alizadeh, \& A. Aldavoodi. 2019b. Effects of cLF-chimera, a recombinant antimicrobial peptide, on intestinal morphology, microbiota, and gene expression of immune cells and tight junctions in broiler chickens challenged with $C$. perfringens. BioRxiv. 2019:1-34. https://doi.org/10.1101/871467

Enany, M., A. E. A. El Gammal, R. Solimane, A. El Sissi, \& A. Hebashy. 2017. Evaluation of lactoferrin immunomodulatory effect on the immune response of broiler chickens. Suez Canal Veterinary Medicine Journal. 22:135-146. https://doi.org/10.21608/scvmj.2017.62452

Fagarasan, S. \& T. Honjo. 2003. Intestinal IgA synthesis: Regulation of front-line body defences. Nat. Rev. Immunol. 3:63-72. https://doi.org/10.1038/nri982

Gadde, U., W. H. Kim, S. T. Oh, \& H. S. Lillehoj. 2017. Alternatives to antibiotics for maximizing growth performance and feed efficiency in poultry: A review. Anim. Health Res. Rev. 18:26-45. https://doi.org/10.1017/ S1466252316000207

Gałecki, A. \& T. Burzykowski. 2013. Linear Mixed-Effects Models Using R. Springer New York. New York, NY. https://doi.org/10.1007/978-1-4614-3900-4

Geier, M. S., V. A. Torok, P. Guo, G. E. Allison, M. Boulianne, V. Janardhana, A. G. D. Bean, \& R. J. Hughes. 2011. The effects of Lactoferrin on the intestinal environment of broiler chickens. Br. Poult. Sci. 52:564-572. https://doi.org /10.1080/00071668.2011.607429

Girard, M. \& G. Bee. 2020. Invited review: Tannins as a potential alternative to antibiotics to prevent coliform diarrhea in weaned pigs. Animal. 14:95-107. https://doi.org/10.1017/ S1751731119002143

Gong, M., D. Anderson, B. Rathgeber, \& J. MacIsaac. 2017. The effect of dietary lysozyme with EDTA on growth performance and intestinal microbiota of broiler chickens in each period of the growth cycle. J. Appl. Poult. Res. 26:1-8. https://doi.org/10.3382/japr/pfw041

Han, S. M., K. G. Lee, J. H. Yeo, B. Y. Oh, B. S. Kim, W. Lee, H. J. Baek, S. T. Kim, S. J. Hwang, \& S. C. Pak. 2010. Effects of honeybee venom supplementation in drinking water on growth performance of broiler chickens. Poult. Sci. 89:2396-2400. https://doi.org/10.3382/ps.2010-00915

Hu, X. F., Y. M. Guo, B. Y. Huang, S. Bun, L. B. Zhang, J. H. Li, D. Liu, F. Y. Long, X. Yang, \& P. Jiao. 2010. The effect of glucagon-like peptide 2 injection on performance, small intestinal morphology, and nutrient transporter expression of stressed broiler chickens. Poult. Scie. 89:1967-1974. https://doi.org/10.3382/ps.2009-00547

Hurwitz, S., A. Bar, M. Katz, D. Sklan, \& P. Budowski. 1973. Absorption and secretion of fatty acids and bile acids in the intestine of the laying fowl. J Nutr. 103:543-547. https:// doi.org/10.1093/jn/103.4.543

Ikeda, Y. 2001. PR-39, a Proline/Arginine-rich antimicrobial peptide, exerts cardioprotective effects in myocardial ischemia-reperfusion. Cardiovasc. Res. 49:69-77. https://doi. org/10.1016/S0008-6363(00)00226-1

Jazayeri, M. H., M. Sadri, A. Mostafaie, \& R. Nedaeinia. 2019. 
Identification of an Immunoglobulin $\mathrm{M}(\operatorname{IgM})$ antibody against Enolase 1 protein (ENO1) derived from HEK-293 cells in patients with kidney failureInt. J. Pept. Res. Ther. 26:1251-1257. https://doi.org/10.1007/s10989-019-09919-y

Jiang, Y. B., Q. Q. Yin, \& Y. R. Yang. 2009. Effect of soybean peptides on growth performance, intestinal structure and mucosal immunity of broilers. J Anim. Physiol. Anim. Nutr. 93:754-760. https://doi. org/10.1111/j.1439-0396.2008.00864.x

Joerger, R. 2003. Alternatives to antibiotics: Bacteriocins, antimicrobial peptides and bacteriophages. Poult. Sci. 82:640647. https://doi.org/10.1093/ps/82.4.640

Johnson, E. A. 2019. Clostridium botulinum; p. 487-512. In Food Microbiology. ASM Press, Washington, DC, USA. https:// doi.org/10.1128/9781555819972.ch18

Józefiak, D., A. Józefiak, B. Kierończyk, M. Rawski, S. Świątkiewicz, J. Długosz, \& R. M. Engberg. 2016. Insects - A natural nutrient source for poultry - A review. Ann. Anim. Sci. 16:297-313. https://doi.org/10.1515/ aoas-2016-0010

Karimzadeh, S., R. M. \& A. T. Yansari. 2016. Effects of canola bioactive peptides on performance, digestive enzyme activities, nutrient digestibility, intestinal morphology and gut microflora in broiler chickens. Poult. Sci. J. 4:27-36.

Karimzadeh, S., M. Rezaei, \& A. Teimouri-Yansari. 2017a. Effect of canola peptides, antibiotic, probiotic and prebiotic on performance, digestive enzymes activity and some ileal aerobic bacteria in broiler chicks. Iranian Journal of Animal Science. 48:129-139. https://doi.org/10.22059/ ijas.2017.221313.653481

Karimzadeh, S., M. Rezaei, \& A. T. Yansari. 2017b. Effects of different levels of canola meal peptides on growth performance and blood metabolites in broiler chickens. Livest. Sci. 203:37-40. https://doi.org/10.1016/j.livsci.2017.06.013

Kierończyk, B., M. Rawski, Z. Mikołajczak, S. Świątkiewicz, \& D. Józefiak. 2020. Nisin as a novel feed additive: The effects on gut microbial modulation and activity, histological parameters, and growth performance of broiler chickens. Animals. 10:101. https://doi.org/10.3390/ani10010101

Kim, D. H., S. M. Han, M. C. Keum, S. Lee, B. K. An, S.-R. Lee, \& K.-W. Lee. 2018. Evaluation of bee venom as a novel feed additive in fast-growing broilers. Br. Poult. Sci. 59:435-442. https://doi.org/10.1080/00071668.2018.1476675

Kim, J.-Y., S.-C. Park, M.-H. Kim, H.-T. Lim, Y. Park, \& K. Hahm. 2005. Antimicrobial activity studies on a trypsinchymotrypsin protease inhibitor obtained from potato. Biochem. Biophys. Res. Commun. 330:921-927. https://doi. org/10.1016/j.bbrc.2005.03.057

King, M. R., V. Ravindran, P. C. H. Morel, D. V. Thomas, M. J. Birtles, \& J. R. Pluske. 2005. Effects of spray-dried colostrum and plasmas on the performance and gut morphology of broiler chickens. Aust. J. Agric. Res. 56:811. https:// doi.org/10.1071/AR04324

Kogut, M. H. 2019. The effect of microbiome modulation on the intestinal health of poultry. Anim. Feed Sci. Technol. 250:32-40. https://doi.org/10.1016/j.anifeedsci.2018.10.008

Krajmalnik-Brown, R., Z. Ilhan, D. Kang, \& J. K. DiBaise. 2012. Effects of gut microbes on nutrient absorption and energy regulation. Nutr. Clin. Pract. 27:201-214. https:// doi.org/10.1177/0884533611436116

Leeson, S. \& J. D. Summers. 2009. Commercial Poultry Nutrition. Third Edition. Nottingham University Press, Nottingham, UK. https://doi.org/10.7313/UPO9781904761099

Li, Y., Q. Xiang, Q. Zhang, Y. Huang, \& Z. Su. 2012. Overview on the recent study of antimicrobial peptides: Origins, functions, relative mechanisms and application. Peptides. 37:207-215. https://doi.org/10.1016/j.peptides.2012.07.001

Li, Z., R. Mao, D. Teng, Y. Hao, H. Chen, X. Wang, X. Wang, N. Yang, \& J. Wang. 2017. Antibacterial and immunomodulatory activities of insect Defensins (DLP2 and DLP4) against multidrug-resistant Staphylococcus aureus. Sci. Rep. 7:12124. https://doi.org/10.1038/ s41598-017-10839-4

Liu, D., Y. Guo, Z. Wang, \& J. Yuan. 2010. Exogenous Lysozyme influences Clostridium perfringens colonization and intestinal barrier function in broiler chickens. Avian Pathol. 39:17-24. https://doi.org/10.1080/03079450903447404

Lu, J., U. Idris, B. Harmon, C. Hofacre, J. J. Maurer, \& M. D. Lee. 2003. Diversity and succession of the intestinal bacterial community of the maturing broiler chicken. Appl. Environ. Microbiol. 69:6816-6824. https://doi.org/10.1128/ AEM.69.11.6816-6824.2003

Lüders, T., G. A. Birkemo, G. Fimland, J. Nissen-Meyer, \& I. F. Nes. 2003. Strong synergy between a eukaryotic antimicrobial peptide and bacteriocins from lactic acid bacteria. Appl. Environ. Microbiol. 69:1797-1799. https://doi. org/10.1128/AEM.69.3.1797-1799.2003

Ma, J. L., L. H. Zhao, D. D. Sun, J. Zhang, Y. P. Guo, Z. Q. Zhang, Q. G. Ma, C. Ji, \& L. H. Zhao. 2020. Effects of dietary supplementation of recombinant plectasin on growth performance, intestinal health and innate immunity response in broilers. Probiotics Antimicrob. Proteins. 12:214-223. https://doi.org/10.1007/s12602-019-9515-2

Macpherson, A. J., \& E. Slack. 2007. The functional interactions of commensal bacteria with intestinal secretory IgA. Curr. Opin. Gastroenterol. 23:673-678. https://doi.org/10.1097/ MOG.0b013e3282f0d012

Malcolm, J. F. 1938. The classification of coliform bacteria. Epidemiol. Infect. 38:395-423. https://doi.org/10.1017/ S0022172400011281

Murguia-Favela, L., N. Sharfe, A. Karanxha, A. Bates, H. Dadi, L. Cimpean, \& C. M. Roifman. 2017. CD40 deficiency: A unique adult patient with hyper Immunoglobulin $\mathrm{M}$ syndrome and normal expression of CD40. LymphoSign Journal. 4:lymphosign-2017-0004. https://doi.org/10.14785/ lymphosign-2017-0004

Ohh, S. H., P. L. Shinde, Z. Jin, J. Y. Choi, T.-W. Hahn, H. T. Lim, G. Y. Kim, Y. Park, K.-S. Hahm, \& B. J. Chae. 2009. Potato (Solanum tuberosum L. cv. Gogu valley) protein as an antimicrobial agent in the diets of broilers. Poult. Sci. 88:1227-1234. https://doi.org/10.3382/ps.2008-00491

Park, S., \& S. M. Yoe. 2017a. A novel Cecropin-like peptide from black soldier fly, Hermetia illucens: Isolation, structural, and functional characterization. Entomol. Res. 47:115-124. https://doi.org/10.1111/1748-5967.12226

Park, S., \& S. M. Yoe. 2017b. Defensin-like peptide3 from black solder fly: Identification, characterization, and key amino acids for anti-Gram-negative bacteria. Entomol. Res. 47: 41-47. https://doi.org/10.1111/1748-5967.12214

Pellegrini, A., U. Thomas, R. von Fellenberg, \& P. Wild. 1992. Bactericidal activities of Lysozyme and Aprotinin against Gram-negative and Gram-positive bacteria related to their basic character. J. Appl. Microbiol. 72:180-187. https://doi. org/10.1111/j.1365-2672.1992.tb01821.x

Pinheiro, J., D. Bates, S. DebRoy, D. Sarkar, EISPACK, S. Heisterkamp, B. Van Willigen, \& R-core. 2020. Linear and Nonlinear Mixed Effects Models. 1-335 p.

Ragland, S. A. \& A. K. Criss. 2017. From bacterial killing to immune modulation: Recent insights into the functions of Lysozyme. PLoS Pathog. 13:e1006512. https://doi. org/10.1371/journal.ppat.1006512

Ren, Z. H., W. Yuan, H. D. Deng, J. L. Deng, Q. X. Dan, H. T. Jin, C. L. Tian, X. Peng, Z. Liang, S. Gao, S. H. Xu, G. Li, \& Y. Hu. 2015. Effects of antibacterial peptide on cellular immunity in weaned piglets. J. Anim. Sci. 93:127-134. https:// doi.org/10.2527/jas.2014-7933

Rowland, I., G. Gibson, A. Heinken, K. Scott, J. Swann, I. Thiele, \& K. Tuohy. 2018. Gut microbiota functions: 
Metabolism of nutrients and other food components. Eur. J. Nutr. 57:1-24. https://doi.org/10.1007/s00394-017-1445-8

Salavati, M. E., V. Rezaeipour, R. Abdullahpour, \& N. Mousavi. 2019. Effects of graded inclusion of bioactive peptides derived from sesame meal on the growth performance, internal organs, gut microbiota and intestinal morphology of broiler chickens. Int. J. Pept. Res. Ther. 26:1541-1548. https://doi.org/10.1007/s10989-019-09947-8

Sauvant, D., P. Schmidely, J. J. Daudin, \& N. R. St-Pierre. 2008. Meta-analyses of experimental data in animal nutrition. Animal. 2:1203-1214. https://doi.org/10.1017/ S1751731108002280

Scanes, C. G., \& K. Pierzchala-Koziec. 2014. Biology of the gastrointestinal tract in poultry. Avian Biology Research. 7:193222. https://doi.org/10.3184/175815514X14162292284822

Schat, K. A., B. Kaspers, \& P. Kaiser. 2013. Avian Immunology. $2^{\text {nd }}$ Ed. Academic Press, Boston.

Shang, Y., S. Kumar, B. Oakley, \& W. K. Kim. 2018. Chicken gut microbiota: Importance and detection technology. Front. Vet. Sci. 5:524. https://doi.org/10.3389/fvets.2018.00254

Shamseer, L., D. Moher, M. Clarke, D. Ghersi, A. Liberati, M. Petticrew, P. Shekelle, \& L. A. Stewart. 2015. Preferred reporting items for systematic review and meta-analysis protocols (PRISMA-P) 2015: elaboration and explanation. BMJ. 349:1-25. https://doi.org/10.1136/bmj.g7647

Sharma, J. M. 2017. Avian Cellular Immunology. CRC Press, Minnesota, MN, USA. https://doi. org/10.1201/9781315137988

Silva, P. I., S. Daffre, \& P. Bulet. 2000. Isolation and characterization of gomesin, an 18-residue Cysteine-rich defense peptide from the spider Acanthoscurria gomesiana hemocytes with sequence similarities to Horseshoe crab antimicrobial peptides of the Tachyplesin family. J. Biol. Chem. 275:33464-33470. https://doi.org/10.1074/jbc.M001491200

Sholikin, M.M., Prihambodo, T.R., Qomariyah, N., Wahyudi, A.T., Jayanegara, A., Nomura, J., Nahrowi. The effect of antimicrobial peptide addition on growth performance, digestibility, small intestine morphology, and blood serum of broiler: A meta-analysis. World's Poultry Sci. J. [Submitted].

St-Pierre, N. R. 2001. Invited review: Integrating quantitative findings from multiple studies using mixed model methodology. J. Dairy Sci. 84:741-755. https://doi.org/10.3168/ jds.S0022-0302(01)74530-4

R Core Team. 2020. R: A Language and Environment for Statistical Computing. p. 1-3690.

Torki, M., D. Schokker, M. Duijster-Lensing, \& M. M. Van Krimpen. 2018. Effect of nutritional interventions with quercetin, oat hulls, $\beta$-glucans, Lysozyme and fish oil on performance and health status related parameters of broilers chickens. Br. Poult. Sci. 59:579-590. https://doi.org/10.1 080/00071668.2018.1496402

Tribst, A. A. L., M. A. Franchi, \& M. Cristianini. 2008. Ultrahigh pressure homogenization treatment combined with lysozyme for controlling Lactobacillus brevis contamination in model system. Innov. Food Sci. Emerg. Technol. 9:265271. https://doi.org/10.1016/j.ifset.2007.07.012

Vizioli, J., P. Bulet, M. Charlet, C. Lowenberger, C. Blass, H.-M. Muller, G. Dimopoulos, J. Hoffmann, F. C. Kafatos, \& A. Richman. 2000. Cloning and analysis of a cecropin gene from the malaria vector mosquito, Anopheles gambiae. Insect Mol. Biol. 9:75-84. https://doi. org/10.1046/j.1365-2583.2000.00164.x
Wang, D., W. Ma, R. She, Q. Sun, Y. Liu, Y. Hu, L. Liu, Y. Yang, \& K. Peng. 2009. Effects of swine gut antimicrobial peptides on the intestinal mucosal immunity in specificpathogen-free chickens. Poult. Sci. 88:967-974. https://doi. org/10.3382/ps.2008-00533

Wang, G., Q. Song, S. Huang, Y. Wang, S. Cai, H. Yu, X. Ding, X. Zeng, \& J. Zhang. 2020. Effect of antimicrobial peptide Microcin J25 on growth performance, immune regulation, and intestinal microbiota in broiler chickens challenged with Escherichia coli and Salmonella. Animals. 10:345. https://doi.org/10.3390/ani10020345

Wang, R., Y. Luo, Y. Lu, D. Wang, T. Wang, W. Pu, \& Y. Wang. 2019. Maggot extracts alleviate inflammation and oxidative stress in acute experimental colitis via the activation of Nrf2. Oxid. Med. Cell. Longev. 2019:1-18. https://doi. org/10.1155/2019/4703253

Wang, S., X. F. Zeng, Q. W. Wang, J. L. Zhu, Q. Peng, C. L. Hou, P. Thacker, \& S. Y. Qiao. 2015. The antimicrobial peptide Sublancin ameliorates necrotic enteritis induced by Clostridium perfringens in broilers. J. Anim. Sci. 93:47504760. https://doi.org/10.2527/jas.2015-9284

Wang, S., X. Zeng, Q. Yang, \& S. Qiao. 2016. Antimicrobial peptides as potential alternatives to antibiotics in food animal industry. Int. J. Mol. Sci. 17:603. https://doi.org/10.3390/ ijms17050603

Wen, L.-F., \& J.-G. He. 2012. Dose-response effects of an antimicrobial peptide, a cecropin hybrid, on growth performance, nutrient utilisation, bacterial counts in the digesta and intestinal morphology in broilers. Br. J. Nutr. 108:1756-1763. https://doi.org/10.1017/S0007114511007240

Wu, Q., J. Patočka, \& K. Kuča. 2018. Insect antimicrobial peptides, a mini review. Toxins. 10:461. https://doi.org/10.3390/ toxins10110461

Xiao, H., F. Shao, M. Wu, W. Ren, X. Xiong, B. Tan, \& Y. Yin. 2015. The application of antimicrobial peptides as growth and health promoters for swine. J. Anim. Sci. Biotechnol. 6:19. https://doi.org/10.1186/s40104-015-0018-z

Yi, H., M. Chowdhury, Y. Huang, \& X.-Q. Yu. 2014. Insect antimicrobial peptides and their applications. Appl. Microbiol. Biotechnol. 98:5807-5822. https://doi.org/10.1007/ s00253-014-5792-6

Yuan, W., H. T. Jin, Z. H. Ren, J. L. Deng, Z. C. Zuo, Y. Wang, H. D. Deng, \& Y. T. Deng. 2015. Effects of antibacterial peptide on humoral immunity in weaned piglets. Food Agr. Immunol. 26:682-689. https://doi.org/10.1080/095401 05.2015.1007448

Yue, S., J. Jie, L. Xie, Y. Li, J. Zhang, X. Lai, J. Xie, X. Guo, \& Y. Zhai. 2020. Antimicrobial peptide CAMA-syn expressed in pulmonary epithelium by recombination adenovirus inhibited the growth of intracellular bacteria. J. Gene Med. 22:0-2. https://doi.org/10.1002/jgm.3149

Zhang, G., G. F. Mathis, C. L. Hofacre, P. Yaghmaee, R. A. Holley, \& T. D. Durance. 2010. Effect of a radiant energytreated Lysozyme antimicrobial blend on the control of clostridial necrotic enteritis in broiler chickens. Avian Dis. Dig. 5: e43-e44. https://doi.org/10.1637/9549-937010-DIGEST.1

Zhang, J., L. Xie, D. Xu, S. Yue, Y. Li, X. Guo, \& X. Lai. 2017. Targeting expression of antimicrobial peptide CAMA-Syn by adenovirus vector in macrophages inhibits the growth of intracellular bacteria. Gene. 630:59-67. https://doi. org/10.1016/j.gene.2017.07.079

Zhao, X., H. Wu, H. Lu, G. Li, \& Q. Huang. 2013. LAMP: A database linking antimicrobial peptides. PLoS ONE. 8:e66557. https://doi.org/10.1371/journal.pone.0066557 